\title{
Construction of Training Mode of Horse Racing International Talents in China's Colleges and Universities
}

\author{
Zhuo Sun, Shuang Zhang * \\ Wuhan Business University, Wuhan 430056, China
}

Keywords: Colleges and universities; horse racing international talents; training mode.

\begin{abstract}
Mainly through literature method, expert interview method and other research methods, this paper analyzes the channel of horse racing talents sources and the existing problems of international talents training of horse racing in colleges and universities, and finally concludes the practice path of constructing international talent training mode of horse racing in China's colleges and universities.
\end{abstract}

\section{Introduction}

In recent years, China's horse racing industry has developed rapidly, there are more and more horse racing events in China, according to statistics, there are horse racing events in the country every day in 2017, more than 500 events are held throughout the year, and the intensity of race is improving year by year. With the increase of events year by year, the quantity and quality of China's imported horses are increasing year by year. Every year, horse owners import horses from Australia, Ireland and other countries by chartered airplane, meantime the price of imported horses is increasing year by year.

At present, the process of international integration is accelerating, as the integration of China's horse industry and international horse industry gradually improve, the expectations and requirements of horse racing talents for horse industry are also improved. China's horse industry should integrate with the world, learn the advanced experience of the countries with developed horse racing, strive to make our horse racing industry bigger and stronger, and even catch up with the countries with developed horse racing, and need more high-quality horse racing talents, especially horse racing international talents.

\section{The Meaning of Horse Racing International Talents}

\subsection{Definition of horse racing international talents}

The horse racing international talents are core talents who have international vision, understand both horse practice and theory, have good English listening, speaking, reading and writing ability, have strong innovative awareness and meet the basic requirements of economic globalization development. They are not only familiar with the current situation of China's horse industry, but also understand the practice of international horse racing industry; they are high-end, complex and practical talents.

\subsection{Quality of horse racing international talent}

Ability to communicate and exchange with international horse racing industry

Western countries such as the United States, Britain and other the countries with developed horse racing, their racing industry chains are complete; the horse racing industry has become the pillar industries of respective countries. At present, the horse racing industry is undergoing a revival in our country, and the industrial chain is not complete, which leads to the lower development level of the whole industry. So development of horse racing in our country need to learn from western the countries with developed horse racing, and it requires the horse industry personnel in our country have communication and exchange ability with western horse racing industry, especially have good English listening, speaking, reading and writing.

Familiar with horse racing culture and industry rules of developed countries

The modern horse industry has more than one hundred years of history in the countries with developed horse racing, various rules and regulations of racing industry in these countries are 
relatively perfect. The perfect rules and regulations guarantee the horse racing industry, and make the horse racing industry gradually develop into a pillar industry of respective countries. As an international horse racing talent, it is necessary to familiarize yourself with the industrial practices and rules of the developed countries. Absorbing its beneficial part and combining with China's national conditions, the industry rules in our country are formulated to promote the development of the racing industry in our country.

Have good horse riding ability

Most of the countries with developed horse racing industry are economically developed countries, at present, the birth rate of these countries is low, and the labor force is short. At the same time, horse racing is a high risk occupation, and the people in the developed countries are not enthusiastic about the work of this field. So far as I know, the horse racing industry in these countries is the shortage of skilled talents, especially the jockey. Therefore, if horse industry practitioners have good horse riding ability, and ride thoroughbred well, such talents are very popular in foreign countries.

\section{The Source Channel of Horse Racing International Talents in China}

\subsection{Training of colleges and universities}

The colleges and universities recruit students to train, which is the most important source channel of horse racing international talent in our country. Wuhan Business University first train students majoring in horse racing in mainland. With the continuous development of horse industry in our country; more than ten universities in our country have opened the related majors of horse racing. It is expected that with the continuous development of horse industry in our country, more and more colleges and universities open horse racing major in the future. The main objects that this paper studies are the international talent of horse racing in colleges and universities.

\subsection{Introduction of foreign countries}

The foreign countries with developed horse racing, especially the United States, Britain and other countries are rich in horse racing talents; we can attract talents to promote the development of horse racing industry in our country through generous treatment. In recent years, with the rapid growth of our country's economy, more and more foreigners come to our country to pan for gold. For example, the head coach of Inner Mongolia Jieshima owners club is the British; our country's larger horse racing clubs have one or two foreign coaches.

\subsection{Horse racing club and independent training of enterprise}

The modern horse racing started in the 1980s in Shenzhen in China, and colleges in China started the horse industry education is in 2008, during this period, China's horse racing talents mainly rely on the horse racing club, the enterprise independently recruit students to train towards society. At present, the mainstay of the horse racing industry in our country are basically trained by the Guangzhou derby twenty years ago and the Beijing Tongshun stud-farm. Entering the 21st century, Wuhan Orient Lucky City opened magic horse class, $t$ and have trained more than 200 elites for our country's horse racing industry. At the same time, various horse racing clubs are also carrying out the training of talents as well.

\subsection{DITI project of Dubai Darley Group}

In order to better develop and promote the horse racing, Prince Mohammed of Dubai established the DITI project. This project is a project for Chinese university students, he select twenty students from the Chinese university students every year, they will be sent to Britain, France, Japan and other countries for a year of nursing, stable practice and so. After the project ends, students are recommended to work in the world and China's top horse racing company. 


\section{The Problems That the Training of Horse Racing International Talents in China's Colleges and Universities Face}

\subsection{Horse racing industry chain is incomplete in our country}

The most important reason for the horse racing industry in countries with developed horse racing industry is that they have horse racing lottery, and horse racing lottery as the core of horse racing event, which drive the development of related industry of horse, and horse racing industry chain is more complete. The horse racing industry has become a huge industry in foreign countries because of the existence of the horse racing lottery, the sales of the 2015 horse racing lottery in Japan were more than 200 billion Yuan RMB. Due to some objective reasons, some guessing lottery in our country, including the horse racing lottery, cannot be publicly issued in the mainland. The lack of horse racing lottery make horse industry chain is not complete in our country; the racing industry chain is still relatively low, so far, it maintains a low-end industrial chain based on horse meat. An industry more thrives and prospers, and the salary treatment of this industry has a large space for development, and high-quality talents will gather in the industry. The horse racing industry in our country is now in a revival stage, so it has little attraction for high-quality talents.

\subsection{Lack of teachers}

The teacher teams are the core force of the training of horse racing international talents, the prerequisite of training horse racing international talent is that the teachers must have international management and teaching level. Because horse racing is an emerging discipline in mainland, the time when Wuhan Business University first opened the horse racing major education is ten years. The colleges and universities that open horse racing education are generally faced with the lack of excellent and qualified teachers. The lack of high-level professional teachers has become the main factor that restricts the training of horse racing international talents.

\subsection{Limited fields and funds}

Horse racing is a noble sport, and the cost of daily feeding and maintenance of horses is high. At the same time, horse racing this sport needs higher requirements for the fields, formal horse racing fields need one 1200 meters of ring runway, meanwhile training fields and stables are needed as well. After development for over ten years, there is basically no free land in the campus for the construction of horse racing fields. In addition, the feeding costs of horse are large, and the feeding cost of a batch of horses is about two, three thousand Yuan or so. Opening horse racing major and training students, the school needs to raise thirty horses to ensure the teaching quality. The expenditure of thirty horses is nearly one hundred thousand a month, which is a heavy financial burden for schools.

\section{Construction of the Practice Path of Training Model Horse Racing International Talent in China}

\subsection{Policy support opening of horse racing lottery and improve big environment of horse racing industry}

Hong Kong has returned to the motherland for nearly twenty years since 1998, Hong Kong's horse racing continued to develop for twenty years, and now the sales of a horse racing day are over 1.6 billion. It is the only way to open the horse racing lottery in order to revitalize and develop the horse racing in the mainland and strive for policy support. Therefore, after the policy support the opening of horse racing lottery, the horse racing industry in mainland will flourish, at that time, more and more people will be eager to enter the horse industry. Good student sources can train more high-quality horse racing international talents for colleges and universities.

5.2 Construction of international professional teachers and management team for horse racing

Teacher is an important force in the internationalization process of colleges and universities, and it is also an important index to measure the internationalization degree of colleges and universities. We should be bold in introducing foreign horse racing professionals and high-level talents from foreign horse racing disciplines as professional teachers, make students' professional knowledge can be integrated with international standards and grasp the industry rules and practices of international horse 
racing industry. In addition, the outstanding young teachers should be given policy to appoint them study the horse racing disciplines of famous universities for long time, through domestic and international academic activities, improve horse racing teachers' academic attainment and level, finally train high-level, master grade horse racing international teacher teams.

\subsection{Develop Chinese and foreign cooperative teaching with the developed horse racing} countries and explore the international cooperative training of horse racing talents

There are over a hundred years of history in the horse industry education in the countries with developed horse racing, and their training mode and curriculum system are more mature and perfect. The education of horse industry in colleges and universities in our country has just started, we should strengthen cooperation with foreign countries, including teachers training, select foreign teachers to teach in China. Meanwhile we have jointly opened "two plus two" and "three plus two" model undergraduate and joint running of undergraduate and postgraduate, and jointly train high-quality international talents for horse racing.

\section{Acknowledgements}

Teaching research project of Wuhan municipal colleges and universities, Research on the international talent training mode of horse racing in Wuhan Business University, Project number: 2017101

\section{References}

[1] Wei Huaying. International Talent Training and Higher Education Internationalization[J], Social Welfare, 2013 (2).

[2] Sun Jianguang, Liu Yujun. Construction of International Talent Training Mode for Local Science and Engineering Universities [J], Continue Education Research, 2013 (9).

[3] Wei Huaying. International Talent Training and Higher Education Internationalization[J], People's Tribune, 2013, (2).

[4] Zhang Rumei. The Innovation and Practice of Chinese International Talents Training Mode Dali University towards Southeast Asia[J], Journal of Dali University, 2012 (7). 